\title{
SISTEM INFORMASI PENANGANAN KELUHAN PELANGGAN DI RUMAH SAKIT UMUM SURYA HUSADHA DENPASAR BERBASIS WEB
}

\author{
Dewa Putu Yudhi Ardiana ${ }^{1}$ I Made Shaja Dwiputra ${ }^{2}$ \\ ${ }^{1,2}$ STMIK STIKOM Indonesia, \\ 1'Email : dewayudhi@stiki-indonesia.ac.id, 2Email : madeshajastiki@gmail.com
}

\begin{abstract}
ABSTRAK
Rumah sakit sebagai salah satu instalasi kesehatan terbesar selalu berupaya melaksanakan pelayanan yang berkualitas karena berdampak pada kepuasan pelanggan dan mendatangkan pelanggan baru. Keluhan pelanggan yang tidak tertangani akan berdampak buruk pada citra rumah sakit. Kesulitan yang dialami oleh Rumah Sakit Umum Surya Husadha Denpasar adalah penanganan keluhan pelanggan yang masih manual dengan menuliskan ke kertas. Cara ini dianggap belum maksimal dalam upaya memberikan penangangan dan mengelola keluhan pelanggan. Tujuan dari penelitian ini adalah membangun sistem informasi penanganan keluhan pelanggan yang dapat membantu pihak customer care rumah sakit dalam mengelola penyampaian keluhan pelanggan, mengkomfirmasi keluhan kepada unit yang terkait dan memvalidasi dari tindakan yang sudah dilakukan. Sistem informasi penangan keluhan pelanggan juga dapat menhasilkan informasi keluhan yang sudah tertangani dan belum tertangani serta laporan keluhan pelanggan berdasarkan unit waktu tertentu. Hasil penelitian menunjukkan telah berhasil membangun aplikasi sistem informasi keluhan yang dapat membantu customer care dalam mengelola keluhan pelanggan. Hasil pengujian black box menunjukkan fungsionalitas sistem dapat berjalan dengan baik.
\end{abstract}

Kata Kunci : Sistem Informasi, Penangan Keluhan, Rumah Sakit,

\begin{abstract}
The hospital as one of the largest health installations always strives to implement quality services because it has an impact on customer satisfaction and brings in new customers. Customer complaints that are not handled properly will adversely affect the impression of the hospital. The difficulty faced by Surya Husadha General Hospital Denpasar is handling customer complaints that are still manual by wrote to the paper. This method is considered not maximal in efforts to provide handling and managing customer complaints. The purpose of this research is to build an information system for handling customer complaints that can help hospital customer care in managing customer complaints, confirm complaints to the relevant units and validate the actions taken. Customer complaint handling information systems can also produce complaints information that has been handled and has not been handled as well as customer complaints reports based on certain time units. The results of the research indicate that it has succeeded in building a complaints information system that can help customer care in managing customer complaints. The results of black box testing show that the system functions run well.
\end{abstract}

Keyword : Informatian System, Complaints Handling, Hospital

\section{PENDAhULUAN}

Salah satu instalasi kesehatan terbesar adalah rumah sakit [1]. Rumah sakit menyediakan layanan kesehatan untuk masyarakat berupa pelayanan medis, pelayanan kefarmasian dan rawat inap. Sebagai salah satu jenis usaha dibidang kesehatan, berbagai rumah sakit berlomba-lomba dalam upaya memberikan pelayanan yang berkualitas untuk mendapatkan kepercayaan masyarakat [2]. Pelayanan yang berkualitas dapat memuaskan pasien/pelanggan sehingga membentuk loyalitas dan berdampak mendatangkan pelanggan baru [3]. Kepuasan hadir dari kesesuian layanan dengan harapan dari pasien tersebut [4].

Ketidaksesuaian antara harapan dan layanan yang didapat akan memunculkan keluhan. Keluhan merupakan bentuk keterbukaan informasi publik [5]. Penyampaian keluhan pelanggan membuka kesempatan rumah sakit untuk melakukan perbaikan terhadap layanan rumah sakit tersebut. Keluhan pelanggan yang tidak tersampaikan dan ditindak lanjuti oleh 
pihak rumah sakit secara tepat akan berdampak buruk pada citra rumah sakit tersebut [6].

Salah satu rumah sakit yang ada di Kota Denpasar adalah Rumah Sakit Umum Surya Husadha yang berdiri sejak 1987. Berawal dari sebuah klinik spesialis THT (telinga, hidung dan tenggorokan) seiring berjalannya waktu klinik dokter spesialis THT ini berkembang dan terus berkembang atas kebutuhan dan kepercayaan dari masyarakat yang senantiasa menekankan pada kekuatan inovasi secara berkesinambungan menjadi sebuah rumah sakit swasta dengan kehadiran unit bangunan baru dengan arsitektur yang di desain berorientasi dengan standar rumah sakit yang ideal dengan nuansa hotel, yang diharapkan mampu memberikan daya dukung pelayanan yang maksimal, suasana nyaman untuk pasien.

Rumah sakit umum surya husadha memiliki berbagai tenaga ahli seperti perawat, dokter umum, dokter spesialis, dokter konsultan hingga seorang professor yang masing-masing mempunyai keahlian dibidangnya. Antara lain ada konsultan urologi, nefrologi, penyakit infeksi dan tropic, gastroenterology, bedah saraf, bedah jantung, dan pembuluh darah, bedah onkologi, bedah ortopedi dan ortopedi anak, bedah anak, spesialis kebidanan \& kandungan, spesialis bedah umum, spesialis anak dan juga spesialis penyakit dalam. Fasilitas yang disediakan oleh rumah sakit seperti kamar yang bersih, pelayanan yang ramah dengan melayani semua pasien dengan hati. Puncak kesuksesan dari rumah sakit adalah dengan diterimanya penghargaan sertifikasi "Paripurna" pada Akreditasi tahun 2016 sebagai rumah sakit dengan standar internasional di bidang Mutu Pelayanan.

Penanganan keluhan yang ada di Rumah Sakit Umum Surya Husadha ditangani oleh bagian customer care. Pasien/pelangan menyampaikan keluhannya melalui ditulis di kertas, telepon ataupun instant messaging. Disediakan kotak saran dimasing-masing lantai dan kamar pasien untuk pasien/pelanggan memasukkan saran ataupun keluhan. Secara berkala customer care akan mengumpulkan kertas tersebut dan menuliskan pada form jika terdapat keluhan yang disampaikan oleh pasien/pelanggan. Setelah dituliskan secara manual keluhan tersebut disampaikan kepada unit yang terkait untuk ditindak lanjuti. Customer care akan memverifikasi keluhan tersebut dan mengkonfirmasi ke pasien/pelanggan. Begitu juga dengan keluhan yang didapat melalui telepon dan instant messaging.

Penanganan yang masih mencatat manual di kertas menimbulkan beberapa masalah seperti pengumpulan kertas dan menginputkan manual di form dan komputer membuat beberapa keluhan harus menunggu kertas untuk dikumpulkan customer care dari kotak saran dan berdampak pada waktu keluhan tersebut sampai ke unit yang ditujukan. Permasalahan berikutnya adalah waktu yang diperlukan customer care untuk menyampaikan dan memverifikasi keluhan tersebut ke unit. Customer care harus membawa keluhan yang terlebih dahulu ditulis dalam form ke unit untuk diverifikasi dan berikan solusi. Permasalahan lainnya adalah manajemen bukti keluhan berupa foto ataupun screenshoot chat keluhan pelanggan.

Berdasarkan permasalahan tersebut, penelitian ini bertujuan untuk membangun sistem informasi penangan keluhan berbasis web. Sistem informasi yang akan dibangun dapat membantu pasien/pelanggan dalam menyampaikan keluhannya, membantu customer care dalam memverifikasi keluhan dan solusi dari unit, mengarsipkan bukti foto dan screenshoot chat keluhan dari pasien/pelanggan dan menghasilkan laporan terkait penanganan keluhan pelanggan. Sistem informasi dikembangkan berbasis web untuk kemudahan akses dari pasien/pelanggan untuk menyampaikan keluhan.

Penelitian ini menggunakan beberapa referensi penelitian terdahulu terkait sistem informasi yang digunakan untuk merancang dan membangun sistem. Beberapa penelitian tersebut antara lain, Penelitian dari Noyfat, Ibrahim dan ambarita yang mengangkat masalah pengaduan pelanggan PDAM Ternate yang dirasa kurang efektif sehingga sebagai solusi dibuatkan sistem informasi pengaduan pelanggan berbasis web. Hasil peneltian tersebut menunjukkan sistem informasi yang dibangun dapat membantu meningkatkan pelayanan dalam hal pengaduan [7]. Penelitian selanjutnya yang digunakan sebagai referensi adalah peneltian dari Anofrisen dkk yang mengangkat permasalahan pencatatan 
proses pengaduan Program Keluarga Harapan yang masih menggunakan hardcopy yang menyebabkan kesulitan pencarian data, ketidakcocokan, pencatatan ganda dan kehilang data. Sehingga solusi dari permasalahan tersebut dibangun sebuah sistem informasi pengaduan masyarakat. Hasil Penelitian tersebut menunjukkan sistem yang dibangun dapat membantu kinerja dari UPPKH Pekanbaru dalam mengelola pengaduan yang masuk [8]. Penelitian ketiga yang digunakan adalah Penelitian dari sofyan dan iryanti yang mengangkat permasalahan penanganan keluhan mahasiswa. Solusi dari permasalahan tersebut dengan membangun aplikasi penanganan keluhan mahasiswa [9]. Penelitian keempat yang digunakan adalah penelitian dari Dermawan dkk yang mengembangkan sistem informasi untuk penanganan keluhan warga berbasis web. Penelitian tersebut mengambil studi kasus Pemerintah Desa Suwaryuwo. Hasil dari penelitian tersebut menunjukkan telah berhasil mengembangkan sistem informasi [10]. Penelitian kelima yang digunakan adalah penelitian dari Hasugian dan Idrus yang merancang dan membangun sistem informasi penanganan keluhan pelanggan yang disebabkan karena pencatatan yang masih manual. Hasil peneltian tersebut menunjukan sistem informasi yang dibangun membantu mempercepat pekerjaan bagian gudang dan divisi IT PT. JASKO PRIMA SEJAHTERA [11]. Selain penelitian diatas beberapa penelitian lain berkaitan dengan pengembang sistem yang pernah penulis kembangkan juga digunakan sebagai referensi [12] [13].

Penelitian ini menggunakan model waterfall untuk mengembangkan perangkat lunak. Beberapa penelitian digunakan sebagai referensi dalam penggunaan model waterfall dalam pengembangan perangkat lunak. Penelitian pertama dari Sahfitri, Nasir dan Sopiah yang menggunakan model waterfall untuk merancang aplikasi $e$ museum sebagai media promosi kain songket khas Palembang. Hasil dari penelitian tersebut menunjukkan berhasil menghasilkan rancangan dari aplikasi berupa use case dan activity diagram [14]. Penelitian kedua dari Sasmito yang menggunakan model waterfall untuk mengembangkan sistem informasi geografis untuk industri di kabupaten Tegal.
Hasil dari penelitian tersebut menghasilkan sistem informasi geografis yang dapat menampilkan data grafik profil industri per kecamatan baik bulanan atuapun tahunan di kabupaten Tegal [15]. Penelitian ketiga dari Dermawan dan Hartini yang mengembangkan sistem informasi perhitungan nilai mata pelajaran berbasis web untuk sekolah dasar. Hasil dari penelitian tersebut menunjukkan telah berhasil mengembangkan sistem informasi menggunakan model waterfall [16].

\section{METODOLOGI}

Penelitian ini menggunakan model waterfall untuk membangun sistem informasi. Model waterfall terkadang disebut siklus hidup klasik dengan pendekatan sekuensial untuk pengembangan perangkat lunak [17]. Terdapat 5 tahapan yaitu communication, planning, modeling, construction, dan deployment.

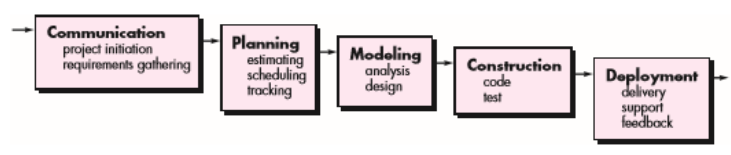

Gambar 1. Model Waterfall

\section{A. Tahapan Communication}

Pada tahapan ini dilaksanakan pengumpulan data. Terdapat 4 metode pengumpulan data yang dilakukan, Metode 1 yaitu observasi, dimana peneliti melakukan pengamatan pada rumah sakit untuk mengetahui alur yang sedang berjalan. Hasil observasi yang peneliti dapat adalah keluhan yang diberikan pelanggan langsung ditangani oleh customer care. Keluhan pelanggan dikelola untuk disampaikan ke unit yang terkait dengan keluhan tersebut. Setelah mengkomfirmasi dan memverikasi permasalahan selanjutnya customer care memasukkan data keluhan ke komputer dengan menggunakan aplikasi Microsoft word.

Metode 2 yaitu wawancara dimana peneliti melakukan wawancara langsung dengan pihak rumah sakit yakni dengan kepala bagian customer care untuk mengetahui permasalahan yang dialami. Hasil wawancara yang didapat adalah pencatatan keluhan dari pasien/pelanggan masih secara manual/ditulis dalam kertas.

Metode 3 yaitu studi kepustakaan yaitu 
peneliti mempelajari buku-buku, literature, jurnal, dan hasil penelitian yang berkaitan dan bisa menunjang pembangunan sistem informasi.

Metode 4 yaitu dokumentasi, dimana peneliti mengambil data dari dokumen customer dokumen penanganan keluhan customer. Dokumen tersebut dipergunakan sebagai dasar dari parancangan sistem yang akan dibangun.

Berdasarkan pengumpulan data yang dilakukan dapat disimpulkan permasalahan yang dialami oleh Rumah Sakit Surya Husadha adalah pencatatan keluhan pelanggan yang masih manual sehingga solusi yang akan dibangun adalah sebuah sistem informasi yang membantu mengelola keluhan pelanggan dan pelaporan keluhan pelanggan. Sistem informasi yang dibangun nantinya mampu untuk menyidakan fasiltas pelanggan dapat menginputkan keluhannya, memproses data keluhan tersebut, mengkonfirmasi ke unit bersangkutan serta memvalidasi solusi yang sudah dilakukan. Sistem juga mampu memproses dan menampilkan laporan berupa informasi keluhan pelanggan setiap hari, minggu, dan bulan.

\section{B. Tahapan Planning}

Tahapan ini peneliti melakukan perencanaan dan pembagian tugas dalam membangun sistem. Melakukan analisis resiko yang mungkin terjadi, sumber daya yang dapat digunakan dan melakukan penjadwalan dalam pengerjaan sistem informasi.

\section{Tahapan Modeling}

Pada tahapan ini dilakukan perancangan sistem informasi menggunakan diagram konteks, Data Flow Diagram (DFD) untuk menggambarkan aliran data dari masukan, proses dan keluaran.

Diagram konteks akan memberi gambaran tentang keseluruhan dari sistem yang akan dibangun. Yang di dalamnya terdapat 4 entitas yaitu entitas customer, entitas customer care, entitas unit dan entitas quality assurance. Secara garis besar customer akan memberikan keluhannya melalui kertas saran, short message service (SMS) atau pesan dari instant messaging ke nomor kontak pengaduan pelayanan customer care yang telah disediakan. Selanjutnya petugas customer care yang menerima keluhan tersebut akan menginput keluhan ke sistem dan sistem otomatis mengkontak unit terkait solusi yang akan akan diberikan terhadap keluhan customer. Pihak customer care akan menginput keluhan tersebut ke sistem serta mengkonfirmasi ke pelanggan melalui nomor kontak yang disediakan. Sedangkan dari Quality assurance akan mendapatkan laporan yang berasal dari pengelolaan keluhan dan melakukan validasi terhadap tindakan yang dilakukan.

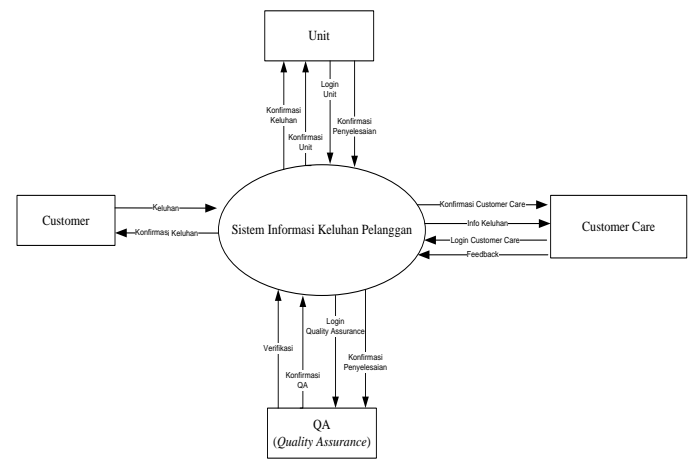

Gambar 2. Diagram Konteks Sistem Informasi Penanganan Keluhan

Diagram konteks selanjutnya dikembangkan menjadi DFD Level 0 yang merupakan detail dari diagram konteks yang sudah dijabarkan sebelumnya pada gambar 1, dimana di DFD level 0 ini mencangkup dari alur proses dari sistem informasi yang akan dibangun. Entitas yang terlibat diantaranya, pengolahan data keluhan, dan penyimpanan data keluhan. Dimana terdapat 5 proses diantaranya memproses keluhan pelanggan (pihak customer yang menulis keluhan saran dan saran), memproses tanggapan pelanggan (dari keluhan yang ditujukan ke unit akan di proses oleh customer care), memproses unit (mengecek kebenaran apakah di unitnya terjadi masalah komplain), memproses laporan pelanggan serta mengelola data user (mengelola user akses dari customer care, unit dan quality assurance. 


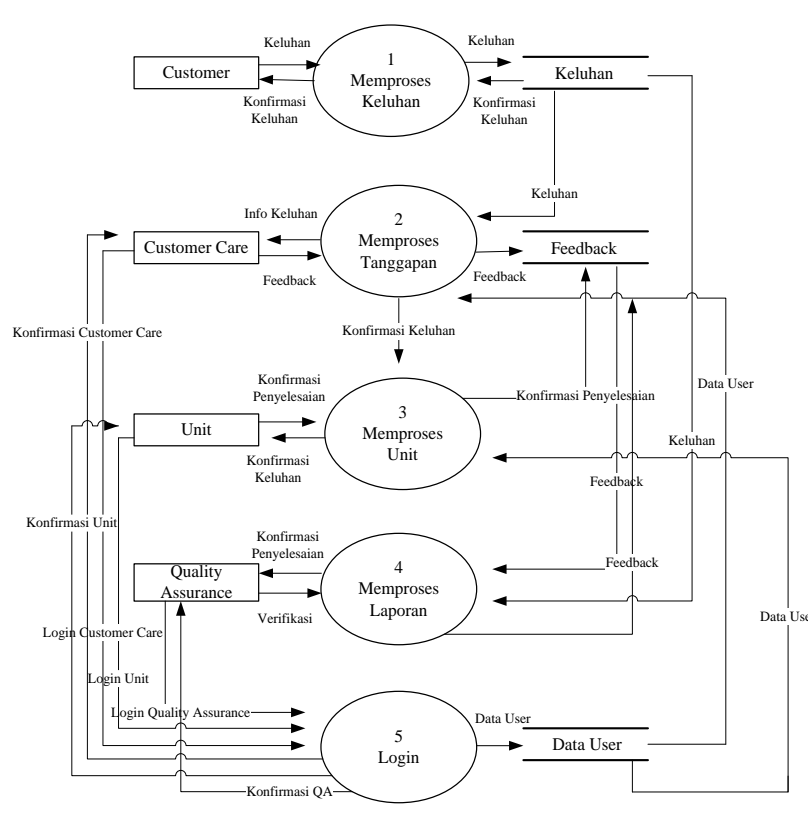

Gambar 3.DFD Level 0 Sistem Informasi Penanganan Keluhan

Didalam DFD Level 1 memproses keluhan terdapat 2 proses yaitu menginput keluhan dan konfirmasi keluhan. Dalam proses menginput keluhan entitas customer menginput keluhan dan disimpan di tabel keluhan, kemudian proses konfirmasi keluhan mengkonfirmasi keluhan ke customer. Data Flow Diagram Level 1 Proses Customer dapat dilihat pada Gambar 3.

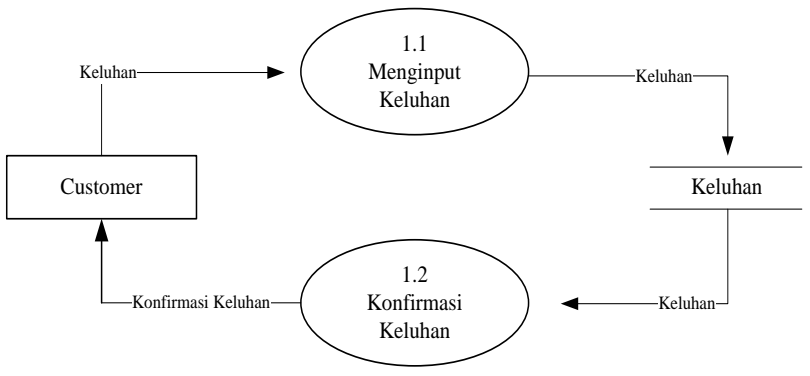

Gambar 4. DFD Level 1 Memproses Keluhan

Didalam DFD Level 1 proses tanggapan ini terdapat entitas customer care yang mendata keluhan serta input feedback keluhan. Data Flow Diagram Level 1 Proses Keluhan dapat dilihat pada Gambar 4.

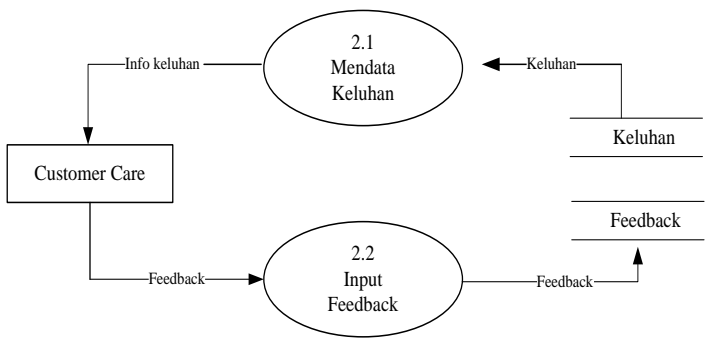

Gambar 5. DFD Level 1 Memproses Tanggapan

Didalam DFD Level 1 proses unit ini terdapat 1 entitas yaitu yang dapat menambahkan data keluhan comment serta melihat data keluhan comment. DFD Level 1 proses unit dapat dilihat pada Gambar 5.

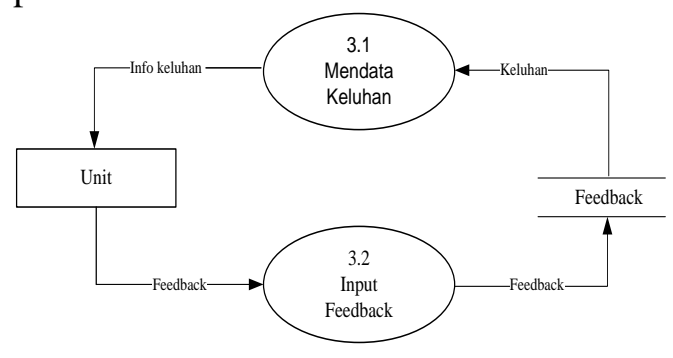

Gambar 6. DFD Level 1 Memproses Unit

Didalam DFD Level 1 proses user ini terdapat entitas user yang dapat mengelola data user, yaitu tambah data user, edit data user, serta cari data user. Data Flow Diagram Level 1 Proses User dapat dilihat pada Gambar 6.



Gambar 7. DFD Level 1 Memproses User

Perancangan dari basis data yang digunakan dalam sistem menggunakan Conceptual Data Model (CDM) dan Physical Data Model (PDM). 


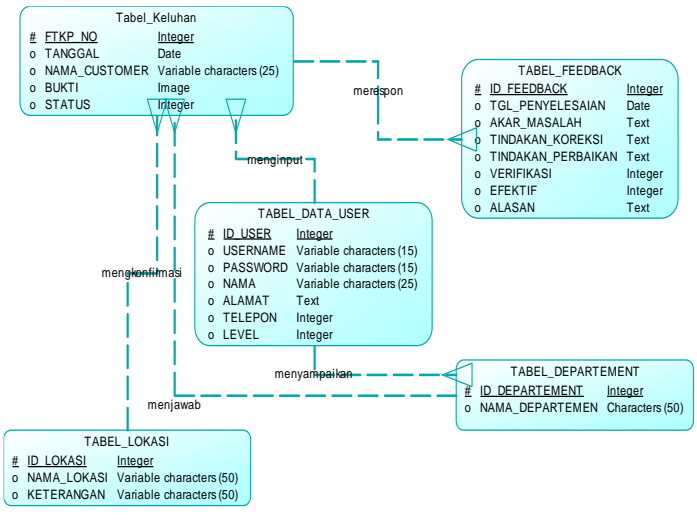

Gambar 8. CDM

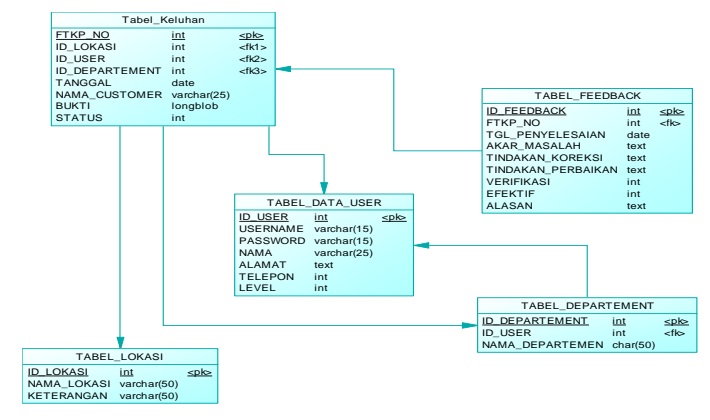

Gambar 9. PDM

\section{Tahapan Construction}

Tahapan ini peneliti melakukan pengkodean bahasa pemrogram PHP untuk membangun sistem informasi berdasarkan rancangan yang sudah dibuat. Setelah dilakukan pengkodean, sistem informasi yang dibangun selanjunya dilakukan pengujian fungsionalitas menggunakan BlackBox Testing. Pengujian bertujuan untuk menemukan kesalahan yang selanjutnya akan diperbaiki.

\section{E. Tahapan Deployment}

Tahapan ini merupakan tahapan terakhir yaitu implementasi sistem informasi pada rumah sakit. Sistem informasi yang diimplementasikan juga dilkaukan pengujian untuk mengetahui kesalahan yang mungkin terjadi dan umpan balik terkait pengembangan sistem informasi selanjutnya.

\section{HASIL DAN PEMBAHASAN}

Halaman login merupakan halaman awal untuk pengguna dapat menggunakan sistem. Pengguna atau user harus memasukkan username dan password untuk dapat masuk ke halaman dashboard pengguna. Jika username dan password benar maka pengguna akan diarahkan ke dashboard sesuai dengan level dari pengguna. Jika username dan password salah maka akan ditampilkan pesan username dan password salah.

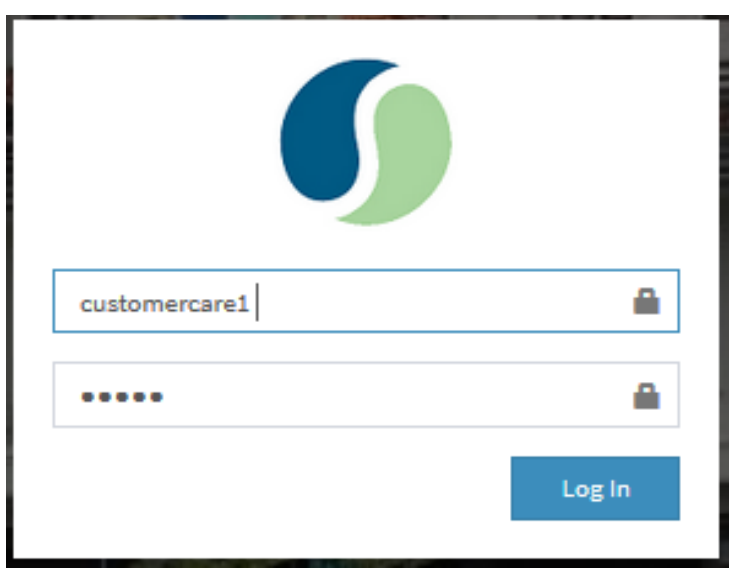

Gambar 10. Halaman Login

Halaman Dashboard customer care berfungsi untuk mengolah dan menampilkan keluhan dari customer atau pelanggan yang masuk ke rumah sakit. Halaman ini hanya dapat diakses oleh pengguna atau user dengan level customer care. Pada halaman ini terdapat tiga buah menu utama yang dapat diakses yaitu manajemen keluhan, manajemen pengguna dan laporan.

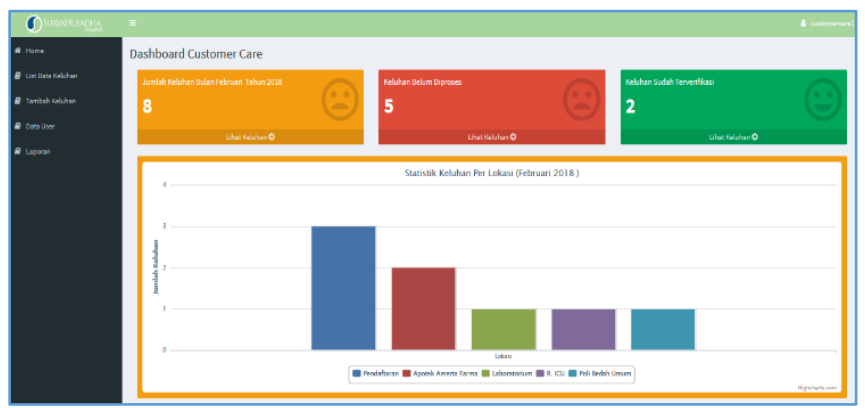

Gambar 11. Halaman Dasboard Customer Care

Halaman list data keluhan berfungsi untuk menampilkan data keluhan dari customer yang ditampilkan dalam bentuk tabel. Dalam halaman ini terdapat tombol proses yang akan digunakan untuk memproses keluhan yang sudah dimasukkan ke dalam sistem. Customer care dapat mencari data melalui fitur pencarian. 


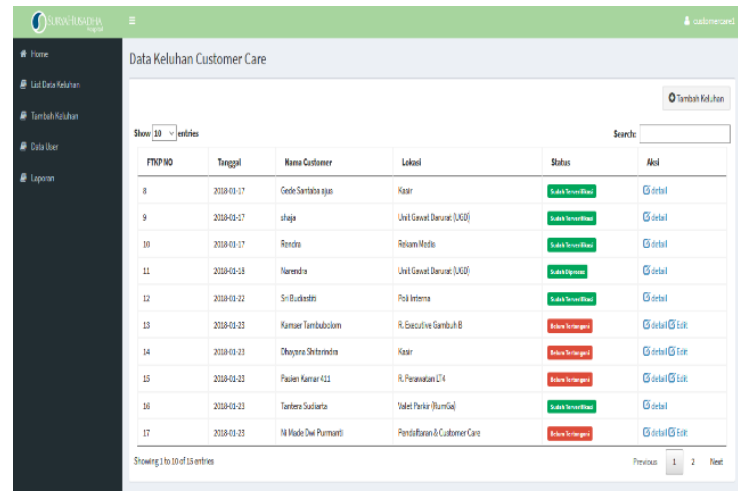

Gambar 12. Halaman List Data Keluhan

Halaman input keluhan merupakan halaman dimana Customer dapat memasukkan keluhan yang dibutuhkan. Halaman ini hanya dapat diakses oleh pelanggan atau customer. Halaman ini berisi beberapa field yang harus diisi oleh customer yaitu nama, telepon, permasalahan, lokasi, serta bukti dari keluhan berupa gambar yang dapat diupload.

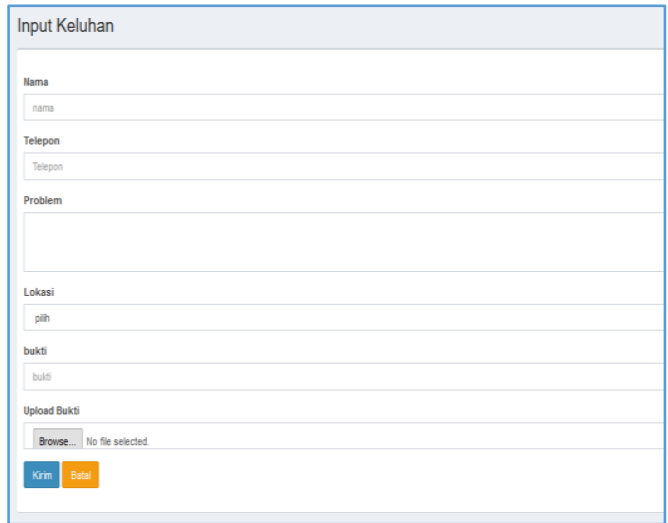

Gambar 13. Halaman Input Keluhan

Halaman dashboard unit merupakan halaman yang dapat diakses oleh bagian unit. Halaman ini akan muncul setelah bagian unit melakukan login. Dalam halaman ini terdapat menu manajemen keluhan dan laporan.

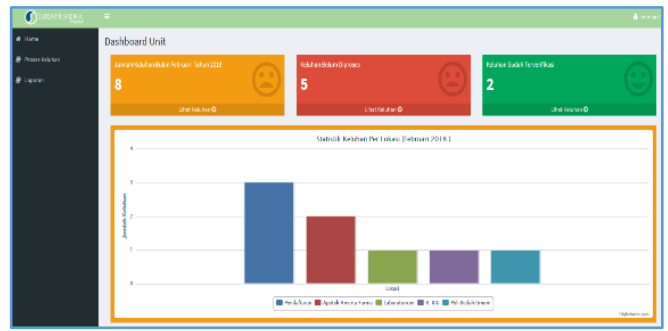

Gambar 14. Halaman Dashboard Unit

Halaman proses keluhan unit merupakan halaman yang berfungsi utuk menampilkan keluhan-keluhan yang sudah diproses oleh customer care dalam bentuk tabel. Setiap unit akan mendapat keluhan yang berbeda-beda sesuai dengan yang ditentukan oleh customer care.

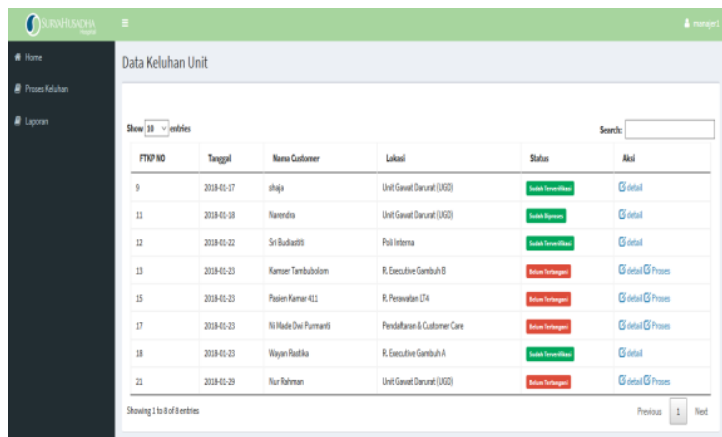

Gambar 15. Halaman Proses Keluhan Unit

Halaman proses keluhan merupakan halaman dimana bagian unit yang mendapatkan keluhan akan memproses keluhan tersebut berupa tindakan sesuai dengan permasalahan yang ada. Setiap unit akan mendapat keluhan yang berbeda-beda sesuai dengan yang ditentukan oleh customer care.

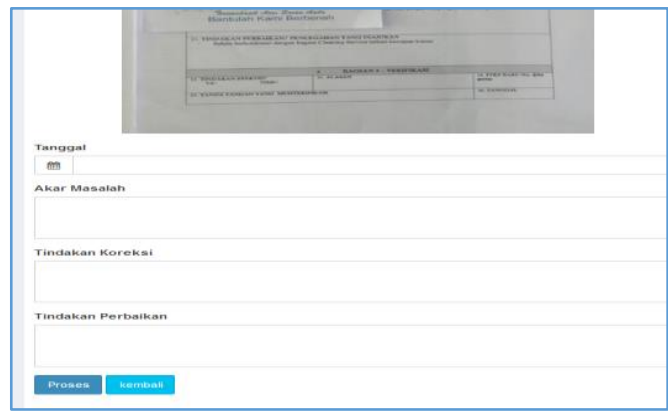

Gambar 16. Halaman Proses Keluhan

Halaman Dashboard Quality Assurance (QA) akan muncul setelah bagian Quality Assurance (QA) login pada sistem. Halaman ini dibuat hanya untuk bagian Quality Assurance (QA). Dalam halaman ini terdapat menu manajemen keluhan dan laporan.

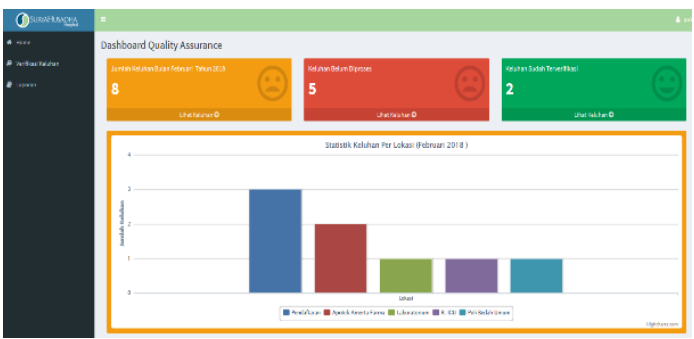

Gambar 17. Halaman Dashboard Quality Assurance (QA) 
Halaman Verifikasi Keluhan Quality Assurance (QA), berfungsi untuk melakukan verifikasi terhadap keluhan yang sudah diproses oleh unit. Quality Assurance (QA) juga dapat melakukan pencarian terhadap keluhan melalui fitur pencarian. Untuk memverifikasi keluhan, QA dapat menekan tombol verifikasi pada masing-masing data keluhan, selanjutnya akan diarahkan menuju proses verfikasi.

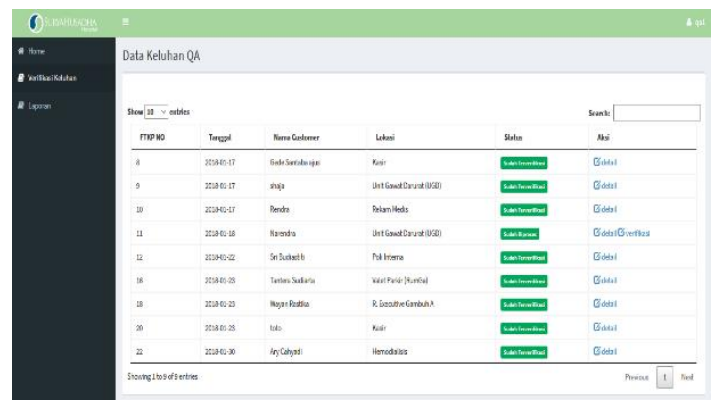

Gambar 18. Halaman Verifikasi Keluhan Quality Assurance (QA)

Pada halaman proses verifikasi Quality Assurance (QA) dapat memeriksa hasil proses dari unit dan menindaklanjuti apakah tindakannya efektif apa tidak, serta memberikan alasan tentang keefektifan dari tindakan yang dilakukan oleh unit.

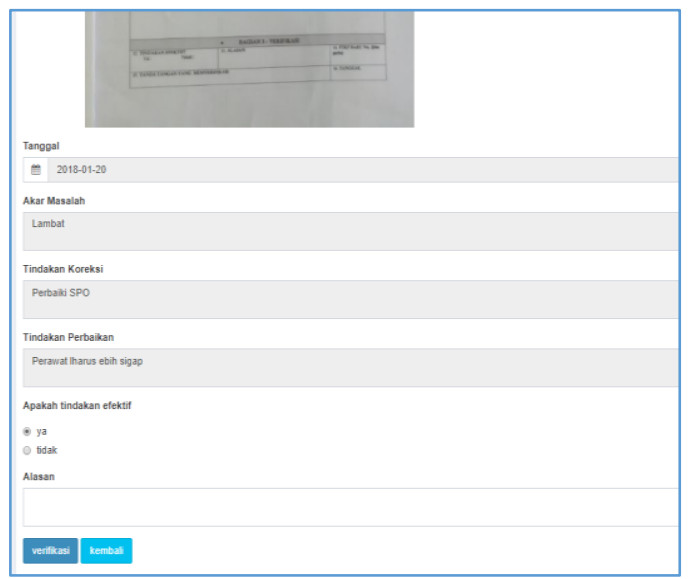

Gambar 19. Halaman Proses Verifikasi

Pada halaman ini customer care dapat mencetak dan melihat detail keluhan yang sudah diproses.

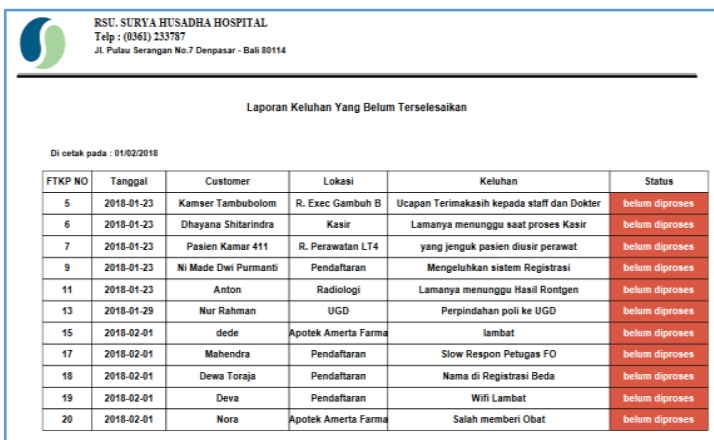

Gambar 20. Halaman Laporan Customer Care

Pada halaman ini Quality Assurance (QA) dapat mencetak dan melihat detail keluhan. $Q A$ juga dapat mencetak keluhan yang sudah terverifikasi.

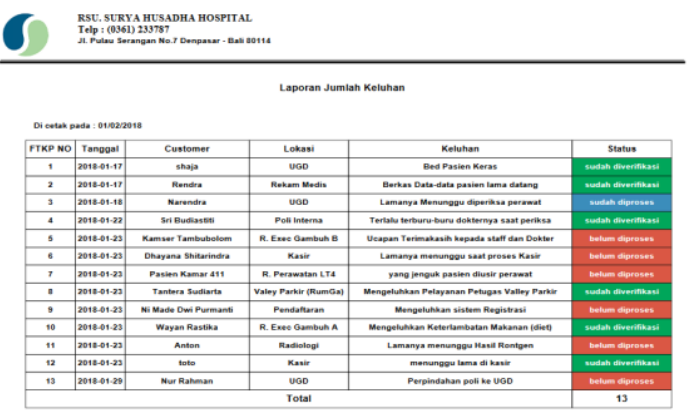

Gambar 21. Halaman Laporan Quality Assurance (QA)

Tabel 1. Pengujian BlackBox

\begin{tabular}{|llll}
\hline N & $\begin{array}{l}\text { Skenario } \\
\text { Pengujian }\end{array}$ & $\begin{array}{l}\text { Hasil yang } \\
\text { Diharapkan }\end{array}$ & $\begin{array}{l}\text { Hasil } \\
\text { Penguj } \\
\text { ian }\end{array}$ \\
\hline $\mathbf{1}$ & $\begin{array}{l}\text { Menambah } \\
\text { kan data } \\
\text { keluhan. }\end{array}$ & $\begin{array}{l}\text { Data tersimpan } \\
\text { di database dan } \\
\text { menampilkan } \\
\text { konfirmasi } \\
\text { keluhan sudah } \\
\text { terkirim. }\end{array}$ & sesuai \\
\hline $\mathbf{2}$ & $\begin{array}{l}\text { Menguploa } \\
\text { d gambar } \\
\text { bukti. }\end{array}$ & Gambar dapat \\
terupload & Sesuai \\
\hline $\mathbf{3}$ & $\begin{array}{l}\text { Mengisi } \\
\text { data yang } \\
\text { salah pada } \\
\text { usernya } \\
\text { selanjutnya } \\
\text { login. }\end{array}$ & $\begin{array}{l}\text { Tetap dihalaman } \\
\text { login. }\end{array}$ & Sesuai \\
\hline
\end{tabular}




\begin{tabular}{lll}
\hline 4 Mengisi & Masuk ke & Sesuai \\
data yang & halaman & \\
benar pada & dashboard & \\
username & sesuai level & \\
dan & pengguna. & \\
passwordn & \\
ya lalu & & \\
login. & &
\end{tabular}

\begin{tabular}{|c|c|c|c|}
\hline 5 & $\begin{array}{l}\text { Memprose } \\
\text { s data } \\
\text { keluhan } \\
\text { dengan } \\
\text { menekan } \\
\text { tombol } \\
\text { proses. }\end{array}$ & $\begin{array}{l}\text { Masuk ke } \\
\text { halaman proses } \\
\text { keluhan sesuai } \\
\text { data yang dipilih }\end{array}$ & Sesuai \\
\hline 6 & $\begin{array}{l}\text { Melakukan } \\
\text { pencarian } \\
\text { pada form } \\
\text { cari. }\end{array}$ & $\begin{array}{l}\text { Menampilkan } \\
\text { data sesuai } \\
\text { dengan kata } \\
\text { kunci yang } \\
\text { dimasukkan }\end{array}$ & Sesuai \\
\hline 7 & $\begin{array}{l}\text { Menekan } \\
\text { tombol } \\
\text { logout }\end{array}$ & $\begin{array}{l}\text { Kembali } \\
\text { halaman login. }\end{array}$ & Sesuai \\
\hline 8 & $\begin{array}{l}\text { Memilih } \\
\text { unit yang } \\
\text { akan } \\
\text { menangani } \\
\text { keluhan. }\end{array}$ & $\begin{array}{l}\text { Menampilkan } \\
\text { data unit pada } \\
\text { combo box. }\end{array}$ & Sesuai \\
\hline 9 & $\begin{array}{l}\text { Menekan } \\
\text { tombol } \\
\text { proses } \\
\text { untuk } \\
\text { memproses } \\
\text { data. }\end{array}$ & $\begin{array}{l}\text { Data tersimpan } \\
\text { pada database } \\
\text { dan kembali ke } \\
\text { halaman keluhan } \\
\text { customer care. }\end{array}$ & Sesuai \\
\hline
\end{tabular}

\begin{tabular}{llll}
\hline $\mathbf{3}$ & tombol & halaman login. & \\
& logout & & \\
\hline $\mathbf{1}$ & Mengisi & Dapat mengisi & Sesuai \\
$\mathbf{4}$ & tanggal tanggal & \\
& prakiraan & prakiraan & \\
& penyelesai & penyelesaian, & \\
& an, akar & akar masalah & \\
& masalah & dan tindakan & \\
& dan & penyelesaian. \\
& tindakan & & \\
& penyelesai & & \\
& an. & &
\end{tabular}

\begin{tabular}{llll}
\hline 1 & Menekan & Data tersimpan & Sesuai \\
$\mathbf{5}$ & tombol & pada database & \\
& proses & dan kembali ke & \\
& untuk & halaman \\
& memproses & manajemen & \\
& data. & keluhan unit. &
\end{tabular}

\begin{tabular}{llll}
\hline 1 & Memverifi & Masuk ke & Sesuai \\
6 & kasi data & halaman proses & \\
& keluhan & verifikasi sesuai & \\
& dengan & data yang dipilih & \\
& menekan & \\
& tombol & \\
& verifikasi. &
\end{tabular}

\begin{tabular}{llll}
\hline 1 & Melakukan & Menampilkan & Sesuai \\
pencarian & data sesuai & \\
pada form & dengan kata & \\
cari. & kunci yang & \\
& & dimasukkan. &
\end{tabular}

\begin{tabular}{llll}
\hline $\mathbf{1}$ & Mengisi & Dapat mengisi & Sesuai \\
$\mathbf{8}$ & efektif & efektif tindakan & \\
& tindakan & dan alasan. & \\
& dan alasan. & &
\end{tabular}

\begin{tabular}{llll}
\hline $\mathbf{1}$ & $\begin{array}{l}\text { Menekan } \\
\text { tombol } \\
\text { logout }\end{array}$ & $\begin{array}{l}\text { Kembali } \\
\text { halaman login. }\end{array}$ & Sesuai \\
\hline $\mathbf{1}$ & Memprose & Masuk ke & Sesuai \\
$\mathbf{1}$ & s data & halaman proses & \\
& keluhan & identifikasi & \\
& dengan & tindakan sesuai & \\
& menekan & data yang & \\
& tombol & dipilih. & \\
& proses. & & \\
\hline $\mathbf{1}$ & $\begin{array}{l}\text { Melakukan } \\
\text { pencarian } \\
\text { pada form }\end{array}$ & $\begin{array}{l}\text { Menampilkan } \\
\text { data sesuai } \\
\text { dengan kata }\end{array}$ & Sesuai \\
& cari. & $\begin{array}{l}\text { kunci yang } \\
\text { dimasukkan. }\end{array}$ & \\
& & &
\end{tabular}

1 Menekan Kembali $\quad$ Sesuai

\begin{tabular}{|c|c|c|c|}
\hline 1 & $\begin{array}{l}\text { Menekan } \\
\text { tombol } \\
\text { verifikasi } \\
\text { untuk } \\
\text { memverifi } \\
\text { kasi data. }\end{array}$ & $\begin{array}{l}\text { Data tersimpan } \\
\text { pada database } \\
\text { dan kembali ke } \\
\text { halaman } \\
\text { manajemen } \\
\text { keluhan } Q A .\end{array}$ & Sesuai \\
\hline $\begin{array}{l}2 \\
0\end{array}$ & $\begin{array}{l}\text { Mencetak } \\
\text { data } \\
\text { keluhan } \\
\text { yang sudah } \\
\text { diproses. }\end{array}$ & $\begin{array}{l}\text { Mencetak data } \\
\text { keluhan yang } \\
\text { sudah diproses } \\
\text { dalam bentuk } \\
\text { PDF. }\end{array}$ & Sesuai \\
\hline $\begin{array}{l}2 \\
1\end{array}$ & $\begin{array}{l}\text { Melakukan } \\
\text { pencarian }\end{array}$ & $\begin{array}{l}\text { Menampilkan } \\
\text { data sesuai }\end{array}$ & Sesuai \\
\hline
\end{tabular}




\begin{tabular}{|c|c|c|c|}
\hline & $\begin{array}{l}\text { pada form } \\
\text { cari }\end{array}$ & $\begin{array}{l}\text { dengan yang } \\
\text { dimasukkan }\end{array}$ & \\
\hline $\begin{array}{l}2 \\
2\end{array}$ & $\begin{array}{l}\text { Mencetak } \\
\text { data } \\
\text { keluhan. }\end{array}$ & $\begin{array}{l}\text { Mencetak data } \\
\text { keluhan } \\
\text { dalam } \\
\text { PDF. }\end{array}$ & Sesuai \\
\hline $\begin{array}{l}2 \\
3\end{array}$ & $\begin{array}{l}\text { Mencetak } \\
\text { data } \\
\text { keluhan } \\
\text { yang sudah } \\
\text { terverifikas } \\
\text { i. }\end{array}$ & \begin{tabular}{lr}
\multicolumn{2}{l}{ Menampilkan } \\
data $\quad$ sesuai \\
dengan yang \\
diinputkan
\end{tabular} & Sesuai \\
\hline $\begin{array}{l}2 \\
4\end{array}$ & $\begin{array}{l}\text { Melakukan } \\
\text { pencarian } \\
\text { pada form } \\
\text { cari }\end{array}$ & $\begin{array}{l}\text { Menampilkan } \\
\text { data sesuai } \\
\text { dengan yang } \\
\text { dimasukkan }\end{array}$ & Sesuai \\
\hline
\end{tabular}

\section{SIMPULAN DAN SARAN}

Berdasarkan hasil dari penelitian yang sudah dilaksanakan dapat disimpulkan sebagai berikut:

1. Sistem informasi penanganan keluhan yang dibangun dapat membantu customer care dalam pengolahan data keluhan pelanggan, meneruskan keluhan kepada unit yang bersangkutan dan memverifikasi penanganan keluhan yang dilakukan oleh unit.

2. Sistem informasi penganganan keluhan ini dapat menghasilkan informasi keluhan pelanggan, keluhan yang belum diproses, keluhan pelanggan yang sudah diproses, keluhan pelanggan yang sudah diverifikasi dan jumlah keluhan berdasarkan lokasi.

3. Hasil pengujian Black Box Testing dari 5 proses dengan 24 skenario pengujian didapat fungsionalitas umum sistem sudah berjalan sesuai harapan.

Untuk pengembangan sistem selanjutnya, maka peneliti memberikan saran sistem informasi ini berbasis mobile agar mudah diakses melalui handphone customer.

\section{REFERENSI}

[1] K. N. Fajrianti and A. Muhtadi, "Review Artikel: Peningkatan Mutu Pelayanan Kesehatan Di Rumah Sakit
Dengan Six Sigma," Farmaka, vol. 15, no. 3, pp. 111-122, 2017.

[2] S. Supartiningsih, "Kualitas Pelayanan an Kepuasan Pasien Rumah Sakit: Kasus Pada Pasien Rawat Jalan," $J$. Medicoeticolegal dan Manaj. Rumah Sakit 10.18196/jmmr.2016, vol. 6, no. 1, pp. 9-15, 2017.

[3] W. Kuntoro and W. Istiono, "Kepuasan Pasien Terhadap Kualitas Pelayanan di Tempat Pendaftaran Pasien Rawat Jalan Puskesmas Kretek Bantul Yogyakarta," J. Kesehat. Vokasional, vol. 2, no. 1, p. 140, 2018.

[4] I. Hadiyati, N. Sekarwana, D. K. Sunjaya, and E. P. Setiawati, "Konsep Kualitas Pelayanan Kesehatan berdasar atas Ekspektasi Peserta Jaminan Kesehatan Nasional Health Service Quality Concept based on Expectation of the National Health Insurance Participants," MKB, vol. 49, no. 2, 2017.

[5] L. Marliana, "Analisis Manajemen Layanan Keluhan Pasien Terhadap Kualitas Layanan Kesehatan Di Rsud. Am. Parikesit Tenggarong," J. Adm. Reform, vol. 5, no. 2, pp. 69-78, 2017.

[6] E. Yonasari, S. P. Arso, and W. Kusumastuti, "GAMBARAN PENANGANAN KELUHAN PELANGGAN DI UNIT CUSTOMER SERVICE RUMAH SAKIT UMUM DAERAH TUGUREJO SEMARANG," J. Kesehat. Masy., vol. 6, no. 5, pp. 6575, 2018.

[7] Nofyat, A. Ibrahim, and A. Ambarita, "INFORMATION SYSTEMS WATER CUSTOMERS COMPLAINTS WEBBASED ON," IJIS, vol. 3, no. April, p. 10, 2018.

[8] Anofrizen, R. Pramudita, N. Safitri, and Y. Sari, "Sistem Informasi Pengaduan Masyarakat Program Keluarga Harapan Kota Pekanbaru ( Studi Kasus: Dinas Sosial dan Pemakaman Kota Pekanbaru )," Ilm. Rekayasa dan Manaj. Sist. Inf., vol. IV, no. 2, pp. 11-20, 2015.

[9] M. R. Sofyan and E. Iryanti, "Aplikasi Penanganan Keluhan Mahasiswa Menggunakan Metode Prototipe," in Seminar Nasional Teknologi Informasi dan Multimedia 2018 UNIVERSITAS AMIKOM Yogyakarta, 2018, pp. 19-24.

[10] M. I. Dermawan, I. Aknuranda, W. 
Hayuhardhika, and N. Putra, "Pengembangan Sistem Informasi Penanganan Keluhan Warga Desa Berbasis Web ( Studi Kasus Pemerintah Desa Suwayuwo )," J. Pengemb. Teknol. Inf. dan Ilmu Komput., vol. 3, no. 2, pp. 1557-1566, 2019.

[11] H. Hasugian and M. Idrus, "Rancang Bangun Sistem Informasi Penanganan Keluhan," in Seminar Nasional Teknologi Informasi dan Komunikasi 2015 (SENTIKA 2015), 2015, vol. 2015, no. Sentika, pp. 143-150.

[12] D. P. Y. Ardiana, I. W. D. Suryawan, and E. Hartono, "Sistem informasi pengelolaan administrasi organisasi kemahasiswaan di stmik stikom indonesia," J. Teknol. Inf. dan Komput., vol. 4, no. 2, pp. 156-165, 2018.

[13] D. P. Y. Ardiana and L. H. Loekito, "Sistem Informasi Peramalan Persediaan Barang Menggunakan Metode Weighted Moving Average," J. Teknol. Inf. dan Komput., vol. 4, no. 1, pp. 71-79, 2018.

[14] V. Sahfitri, M. Nasir, and N. Sopiah, "Perancangan electronic Museum (eMuseum) sebagai Media Promosi Kain Songket Khas Palembang," J. Inform. J. Pengemb. IT, vol. 3, no. 3, pp. 354-360, 2019.

[15] G. W. Sasmito, "Penerapan Metode Waterfall Pada Desain Sistem Informasi Geografis Industri Kabupaten Tegal," $J$. Pengemb. IT, vol. 2, no. 1, pp. 6-12, 2017.

[16] J. Dermawan and S. Hartini, "IMPLEMENTASI MODEL WATERFALL PADA PENGEMBANGAN BERBASIS WEB PADA SEKOLAH DASAR ALAZHAR SYIFA BUDI JATIBENING," Paradigma, vol. 19, no. 2, 2017.

[17] R. S. Pressman, Software Engineering: A Practitioners Approach" 7TH EDITION. McGraw-Hill Publishing Company, 2010. 